\title{
PERSPEKTIF MAHASISWA BERLATAR JURUSAN KEISLAMAN TERHADAP PEMBELAJARAN BAHASA INGGRIS
}

\author{
Qori'ah Maghfirotillah, Latifatul Fajriyah, Alfan Hariri \\ (Alumni UIN Sunan Ampel Surabaya)
}

\begin{abstract}
Abstrak:
Penelitian ini bertujuan untuk mengetahui perspektif mahasiswa dengan latar jurusan keislaman terhadap pembelajaran Bahasa Inggris. Dua pertanyaan yang dikemukakan, yakni: 1) Apa perspektif mahasiswa dengan latar jurusan keislaman di UIN Sunan Ampel Surabaya tentang pentingnya belajar Bahasa Inggris?, 2) Apakah pembelajaran Bahasa Inggris yang dilakukan di UIN Sunan Ampel Surabaya dapat membantu mahasiswa dengan latar jurusan keislaman untuk memahami disiplin keilmuan terkait? Mixed method dipilih sebagai metode untuk melakukan pengumpulan dan analisis data. Dalam pertanyaan pertama, bentuk survey dipilih sebagai metode penelitian, dengan instrumen berupa angket. Angket yang digunakan berisi sepuluh pertanyaan yang disebarkan kepada 100 orang mahasiswa. Untuk pertanyaan kedua, pendekatan kualitatif dirasa cocok dan dipilih sebagai metode untuk memperoleh jawaban. Wawancara digunakan sebagai tehnik pengumpulan data dan melibatkan 25 mahasiswa sebagai informan. Pada akhirnya, ditemukan bahwa mahasiswa berlatar jurusan keislaman memiliki persepsi positif terkait dengan pentingnya mempelajari Bahasa Inggris. Selain itu, hasil penelitian juga menunjukkan bahwasannya proses pembelajaran Bahasa Inggris di UIN Sunan Ampel oleh sebagian besar informan dianggap belum berjalan efektif dan tidak memberikan banyak kontribusi dalam upaya meningkatkan kemampuan Bahasa Inggris dan menghubungkannya dengan disiplin keilmuan terkait. Dengan demikian, persepsi positif mahasiswa tentang pentingnya mempelajari Bahasa Inggris belum difasilitasi dengan cukup baik oleh pembelajaran yang berlangsung.
\end{abstract}

Kata Kunci : Perspektif Mahasiswa, Latar Jurusan Keislaman, Pembalajaran Bahasa Inggris. 


\begin{abstract}
:
This research's goal is to know the perspective of Islamic studies students towards English learning process. For reaching this goal, there are two research questions: 1) what is the perspective of Islamic studies students towards English learning process in State Islamic University of Sunan Ampel Surabaya? 2) how does English learning process help Islamic studies students in State Islamic University of Sunan Ampel Surabaya to enrich their field study knowledge?. Mixed method was chosen as the method to collect and analysis the data. To answers the first research question, survey was used as research method, and questioner was used as instrument. There were 10 statements in the questioners that were given to 100 participants. Meanwhile, to answer the second research question, qualitative approach was chosen as method to gain answer. Interview was used as data collecting technique that involved 25 participants as informant. Finally, it was found that Islamic studies students had positive perception dealing with the importance of learning English. The result also showed that English learning process on most of students' perspective had not been effective and it did not give much contribution in increasing students' English ability which deals with their disciplines. In conclusion, positive perception of students about the importance of learning English was not facilitated enough by learning process.
\end{abstract}

\title{
Keywords: Students' Perspective, Islamic Majors, English Language Learning.
}

\section{A. Pendahuluan}

Pada era gloalisasi, batasan suatu negara sudah tidak berarti lagi bagi masyarakat dunia. Hal ini dikarenakan globalisasi membuat dunia menjadi semakin sempit. ${ }^{1}$ Masyarakat dunia mampu melampaui batasan-batasan tersebut dengan penguasaan bahasa global sebagai alat komunikasi. Oleh itu, bahasa global menjadi sangat penting karena fungsinya sebagai pemersatu pelbagai suku, bangsa, etnik, serta agama di seluruh dunia. Selain itu, bahasa global juga berfungsi sebagai alat penyampai informasi dari satu individu atau kelompok kepada individu atau kelompok yang lain di seluruh dunia. Saat ini, bahasa global yang banyak masyarakat dunia gunakan adalah Bahasa Inggris. ${ }^{2}$

\footnotetext{
${ }^{1}$ Zuliati Rohmah, "English as A Global Language: Its Historical Past and Its Future". Indonesian Scientific Journal Database. 1(Vol. 33, 2005,) 106.

2 Ibid.
} 
Bahasa Inggris menjadi global lingua franca (bahasa penghubung) utama karena dua hal, yaitu geografis-sejarah dan sosial-budaya. ${ }^{3}$ Bahasa Inggris, diguna-sebarkan dalam dunia global melalui migrasi orang-orang yang berbahasa Inggris, penjajahan oleh orang Inggris, peran dan pengaruh Amerika dalam skala global, komunikasi internasional, media, film, teknologi, dan lain-lain. Selain itu, Bahasa Inggris menjadi bahasa utama dalam perdagangan, diplomasi, dan juga pendidikan di dunia. Pada zaman mutakhir seperti sekarang ini, banyak penelitian dan sumber-sumber ilmu pengetahuan yang ditulis dan dipresentasikan dalam Bahasa Inggris. Sehingga, menguasai Bahasa Inggris dapat menjadi salah satu pintu untuk menguasai pengetahuan-pengetahuan mutakhir.

Sejak periode 1750-1900, ilmu pengetahuan dan teknologi telah banyak ditulis menggunakan Bahasa Inggris. ${ }^{4}$ Ini mempengaruhi pengguna sumbersumber dalam Bahasa Inggris seperti para akademisi dan mahasiswa. Sumbersumber ilmu pengetahuan yang ditulis dalam Bahasa Inggris dapat berupa buku, artikel, maupun jurnal. Hal ini menuntut mereka untuk bisa berbahasa Inggris secara tulisan maupun lisan. Seorang akademisi atau mahasiswa akan diakui karya-karyanya secara luas bila mereka bisa menciptakan suatu terobosan yang bermanfaat bagi dunia yang biasanya ditulis atau dipresentasikan kepada masyarakat dunia menggunakan bahasa global, yakni Bahasa Inggris. Bahasa Inggris digunakan tidak terbatas pada semua sektor, ini karena Bahasa Inggris sebagai penunjang sarana komunikasi seluruh warga dunia tentang berbagai lini.

Dalam dunia pendidikan, Bahasa Inggris adalah bahasa pengantar dalam lingkup ilmu multidisipliner. Penggunaan Bahasa Inggris dalam bidang ilmu multidisipliner ini melahirkan English for Specific Purpose (ESP) yang berfokus pada pemerolehan keahlian profesional yang terintegerasi dengan beragam kecakapan, disipliner, dan praktek. $^{5}$ Misalnya, Bahasa Inggris dalam dunia Pendidikan, Kesehatan, Ekonomi, Hukum, Agama, dan lain-lain. ESP bertujuan untuk mempermudah komunikasi antar pelaku suatu bidang tertentu. Sehingga, pembelajaran ESP dalam dunia akademik sangat dianjurkan untuk digalakkan, mengingat setiap bidang selalu mengalami perkembangannya sendiri.

Melihat realita tersebut, Universitas Islam Negeri (UIN) Sunan Ampel Surabaya sebagai salah satu Universitas Islam di Indonesia yang memiliki berbagai disiplin ilmu pengetahuan bertujuan untuk menjadi kampus kelas dunia yang menjunjung tinggi penguasaan Bahasa Asing, baik Bahasa Arab ataupun Bahasa Inggris. Hal ini dibuktikan dengan adanya pembelajaran Bahasa Asing

${ }^{3}$ David Crystal, English as Global Language (New York: Cambridge University Press, 2003), 29.

${ }^{4}$ Ibid, 81.

5 Vijay Bhatia, et al, ESP in the 21th Century: ESP Theory and Application Today. Proceeding of JACET 50th Commerative International Convention. 
secara intensif untuk mahasiswa baru. Selain itu, Bahasa Asing dipelajari oleh mahasiswa berbagai jurusan di UIN Sunan Ampel yang masuk pada mata kuliah reguler sebagai penunjang perkuliahan. Itu dikarenakan referensi-referensi yang dipakai mahasiswa UIN Sunan Ampel tidak terpaku pada referensi yang berbahasa Indonesia.

Abad ini, kajian keislaman tidak melulu dapat diakses melalui referensi berbahasa Arab, namun juga literatur yang berbahasa Inggris. Jika banyak mahasiswa UIN yang berlatar belakang santri, bukanlah menjadi suatu kesulitan bagi mereka untuk mengakses sumber berbahasa Arab. Namun, jika mereka diharuskan mengakses sumber belajar yang berbahasa Inggris, hal ini kemudian timbul sebagai permasalahan. Dari latar belakang tersebut, peneliti mencoba untuk mengungkap pandangan mahasiswa yang berlatar belakang jurusan keislaman terhadap pembelajaran Bahasa Inggris di UIN Sunan Ampel. Penelitian ini dilakukan pada April hingga Agustus 2015.

\section{B. Pertanyaan Penelitian}

Dengan melihat fakta-fakta yang telah dijelaskan dalam hal-hal yang melatarbelakangi dilaksanakannya penelitian ini, terdapat dua pertanyaan yang peneliti coba jawab terkait dengan persepsi Mahasiswa dengan latar keilmuan agama Islam terhadap pembelajaran bahasa Inggris. Berikut adalah formulasi pertanyaan yang diajukan: Apa perspektif mahasiswa dengan latar jurusan keislaman di UIN Sunan Ampel Surabaya tentang pentingnya belajar Bahasa Inggris?; dan Apakah pembelajaran Bahasa Inggris yang dilakukn di UIN Sunan Ampel Surabaya dapat membantu mahasiswa dengan background pendidikan Islam untuk memahami disiplin keilmuan terkait?

\section{TujuanPenelitian}

Berkaitan dengan latar belakang dan formulasi pertanyaan dalam penelitian ini, rangkai kata di bawah ini dimaksudkan sebagai tujuan yang ingin dicapai oleh dilaksanakannya penelitian: Untuk mengetahui apa dan bagaimana mahasiswa berlatar jurusan keislaman di UIN Sunan Ampel Surabaya terhadap pentingnya mempelajari Bahasa Inggris; dan Untuk mengetahui pandangan mahasiswa tentang apakah pembelajaran Bahasa Inggris yang didapat di UIN Sunan Ampel Surabaya dapat membantu mereka memahami disiplin keilmuan terkait. 


\section{Kerangka Teori}

1. Bahasa Inggris sebagai Bahasa Global

Pada abad ini, Bahasa Inggris menjadi bahasa global dunia. Di dunia manapun seseorang berada, selama menggunakan Bahasa Inggris maka komunikasi akan dipahami oleh lawan bicaranya. Seperti contoh di Bali, semua pengunjung Internasional menggunakan Bahasa Inggris sebagai bahasa utama dalam berkomunikasi dengan masyarakat lokal. Begitu juga, apabila berkunjung ke negara lain maka bahasa yang digunakan untuk berkomunikasi adalah bahasa global, Bahasa Inggris.

Bahasa Inggris tidak hanya menjadi bahasa internasional yang hanya digunakan ketika terjadi komunikasi antara dua orang yang berasal dari dua negara atau lebih ${ }^{6}$. Seperti contoh, Bahasa Arab, yang merupakan bahasa internasional, digunakan ketika orang dari negara yang berbeda bertemu dengan orang Arab. Begitu pula Bahasa Jepang, digunakan hanya saat seseorang berada di lingkungan yang orang, tradisi ataupun bisnisnya didominasi oleh orang yang berbahasa Jepang. Hal ini berbeda dengan Bahasa Inggris yang penggunaanya menyebar di seluruh dunia sekalipun tidak ada hubungannya sama sekali dengan negara-negara yang berbahasa Inggris. Dengan kata lain, Bahasa Inggris adalah lingua franca dunia yang menjadi alat komunikasi antara orang-orang yang berbeda negara. Berdasarkan fakta inilah, Bahasa Inggris kemudian dikatakan sebagai bahasa global.

Sebagai bahasa global, tentu penggunaannya bukan hanya sebagai media berkomunikasi secara verbal, melainkan juga dalam berbagai segi kehidupan seperti bahasa pemprograman komputer, buku panduan produk, sumber-sumber pendidikan, ekonomi dll7. Bahkan, dalam kurikulum pendidikan, Bahasa Inggris tidak hanya diajarkan di negara yang berbahasa Inggris sebagai bahasa utama, tetapi hampir di semua negara di seluruh dunia ${ }^{8}$. Dengan penggunaan yang sangat masif hampir di seluruh aspek kehidupan, maka mempelajari Bahasa Inggris menjadi kebutuhan yang tidak bisa dipungkiri.

${ }^{6}$ Zuliati Rohmah, "English as global Language”, Journal Bahasa dan Seni, (Universitas Negeri Malang, 2015).

7 David Crystal, English as a global language. (Cambridge: Cambridge University Press, 1997).

${ }^{8}$ David Graddol, The Future Of English?. (London: The British Council. 1997). 
2. Sumber-Sumber Pengetahuan Berbahasa Inggris

Dengan statusnya sebagai bahasa global, Bahasa Inggris tentunya digunakan juga dalam hal publikasi mulai dari buku, jurnal, penelitian, dan seminar ilmiah. Hal ini bertujuan untuk memperlebar jangkauan dari pembaca atau peserta dari buku atau seminar yang dilaksanakan. Dengan kata lain, seorang peneliti dan ilmuan, apabila ingin hasil karyanya memiliki pengaruh dan dikenal secara interasional, maka mereka harus mempublikasikannya dengan menggunakan Bahasa Inggris ${ }^{9}$.

Terkait dengan penggunaan Bahasa Inggris, data menunjukkan bahwa sekitar satu milliar website menggunakan Bahasa Inggris dari berbagai bidang keilmuan yang akan memberikan kemudahan kepada pengakses untuk mendapatkan informasi. Lebih jauh lagi, diketahui bahwasannya publikasi hasil penelitian yang mencapai $95 \%$ ditulis dengan berbahasa Inggris $^{10}$. Ditambah dengan buku-buku pengetahuan baik yang di tulis oleh pengarang Inggris, Amerika ataupun hasil terjemahan dari bahasa lain ${ }^{11}$. Dari sumbersumber tersebut, termasuk di dalamnya sumber pengetahuan yang berkaitan dengan agama.

Hal ini tentunya sangat membantu para akademisi untuk memperluas pengetahuan, khususnya dengan berdasrkan pada sumber nan mutakhir. Hal ini dikarenakan selalu berkembangnya ilmu pengetahuan agama yang ditandai dengan diadakannya penelitian-penelitian terbaru dan berkelanjutan; terorisme, radikalisme, agresi ISIS, dll. Selain itu, Bahasa Inggris menjadi bahasa utama dalam sumber yang membahas agama-agama yang muncul di daerah Eropa seperti Kristen dan katolik. Dengan pengayaan sumber pengetahuan agama, maka hal ini juga akan menambah khazanah keilmuan dalam bidang tersebut. Salah satu contohnya, para akademisi bisa memiliki sudut pandang dari kacamata yang berbeda terutama dari kelompok yang berbeda.

3. Pentingnya Bahasa Inggris Bagi Mahasiswa dengan Latar Jurusan Keislaman

Sebagai akademisi, mahasiswa dituntut untuk selalu kritis dalam menanggapi setiap isu baik nasional ataupun internasional. Untuk memenuhi tantangan tersebut, dibutuhkan sebuah pemahaman yang utuh sehingga dapat dihasilkan respon yang objektif dan komprehensif. Seperti contoh,

\footnotetext{
9 The Atlantic. 2015. The Hidden Bias of Science's Universal Language. www.theatlantic.com. (Diakses pada 10 April 2015).

10 Robert B Kaplan, Language in The Global Context: Implication for The Language Classrooms (Singapore: SEAMEO RECL, 2000)

11 -.--, 2015. Why Learn English, www.antimoon.com. (Diakses pada 10 April 2015)

Jurnal Pendidikan Agama Islam

Volume 3 Nomor 2 November 2015

ISSN: 2089-1946

Hal. 262 - 275
} 
mahasiswa perbandingan agama; ketika mereka membahas tentang agama Kristen dan katolik maka rujukan utama yang dipakai adalah buku atau jurnal terbitan dari negara-negara Eropa yang tentunya menggunakan Bahasa Inggris. Sehingga, penguasaan Bahasa Inggris yang baik dapat membantu mahasiswa untuk memperkaya wawasan terkait bidang keilmuan yang ditekuni' ${ }^{12}$.

Melihat fenomena bahwa pembahasan isu-isu keagamaan pada saat ini banyak menggunakan Bahasa Inggris, sudah menjadi kemestian bahwa mahasiswa yang berlatar pendidikan keagamaan perlu menguasai Bahasa Inggris sebagai alat untuk mengetahui isu agama kekinian serta untuk menerbitkan hasil pemikiran dan penelitiannya.

4. Perspektif mahasiswa terhadap Pembelajaran Bahasa Inggris

Dalam sebuah proses pembelajaran, perspektif dari setiap individu sangat berperan dalam proses pencapaian tujuan dari pembelajaran yang dilakukan. Perspektif akan berpengaruh terhadap perilaku, sikap, respon dan motivasi yang dimiliki ${ }^{13}$. Dengan kata lain, perspektif yang positif terhadap sesuatu akan membuat seseorang memiliki motivasi untuk mewujudkan sesuatu tersebut. Seperti contoh, ketika seseorang memiliki perspektif yang positif terhadap Bahasa Inggris, maka mereka akan berupaya untuk mempelajari dan menguasainya dengan mengikuti kegiatan pembelajaran di kelas dengan baik atau bahkan akan mencari kelas atau aktifitas tambahan untuk meningkatkan kemampuannya. Begitu pula sebaliknya, ketika seseorang bersikap apatis terhadap Bahasa Inggris, maka sikap malas untuk mengikuti kegiatan pembelajaran akan timbul. Dampak yang akan timbul kemudian ialah bahwa mahasiswa tersebut tidak akan berpartisipasi secara maksimal di dalam kelas.

Terkait dengan hal ini, Dornyei menyarankan untuk menjelsakan tentang pentingnya materi yang diajarkan kepada siswa di setiap awal pelajaran ${ }^{14}$. Hal ini ditujukan agar mahasiswa tahu bahwa pembelajaran yang dilakukan akan mampu membantunya untuk meningkatkan kompetensi yang dimiliki. Menurut Lightbown, sekalipun tidak ada penelitian yang membuktikan bahwa perspektif berpengaruh pada tercapainya tujuan

12 Muhammad H. Al-Khairi, "English as A Foreign Language Learning Demotivational Factors As Perceived By Saudi Undergraduates", European Scientific Journal, 9 (November, 2013,)

13 Ismail sheikh Ahmad, et al., "Attitudes and Motivation toward Learning the English Language among Students from Islamic Education System Background: Exploring the Views of Teachers", Journal of Education and Learning. 3 (Vol.8, 2014,) 195-208.

${ }^{14}$ Zoltan Dornyei, Teaching and Researching motivation (Harlow: Longman, 2001) 
pembelajaran, akan tetapi ada cukup banyak bukti berdasarkan pengalaman bahwa perspektif positif berkaitan dengan kemauan untuk tetap belajar ${ }^{15}$. Dengan kata lain, perpektif mahasiswa merupakan bagian tak terpisahkan dari proses pembelajaran.

Dengan alasan-alasan di atas, menjadi sangat penting bagi mahasiswa untuk memiliki perspektif positif terhadap pembelajaran Bahasa Inggris yang ada di UIN Sunan Ampel, khususnya bagi mahasiswa jurusan yang berlatar belakang keislaman. Sehingga, tenaga pengajar harus menjadikan perspektif sebagai salah satu pertimbangan utama demi tercapainya tujuan pembelajaran yang di inginkan.

\section{E. Metodologi Penelitian}

1. Desain Penelitian

Penelitian ini menggunakan model pendekatan campuran atau yang biasa dikenal dengan mixed method untuk melakukan usaha pencarian jawaban. Creswell mendefinisikan mixed method sebagai serangkaian prosedur dalam pengambilan serta analisis data yang mengoptimalkan pemakaian baik kualitatif dan kuantitatif. ${ }^{16}$ Dalam penelitian ini, pendekatan kuantitatif digunakan untuk menjawab pertanyaan pertama, sedangkan pendekatan kualitatif digunakan untuk menjawab pertanyaan kedua.

Untuk menjawab pertanyaan pertama, tipe penelitian kuantitatif yang digunakan ialah studi survei. Dijelaskan oleh Creswell, studi survei adalah serangkaian prosedur dalam penelitian kuantitatif, di mana biasanya angket digunakan sebagai instrumen pengambilan data, yang ingin mendeskripsikan sikap, opini, perilaku, atau sifat dari sekelompok sampel atau populasi. ${ }^{17}$ Studi survei tidak menggunakan manipulasi dalam proses penelitian. Dalam arti lain, yang dilakukan dalam studi survei ialah sebatas deskripsi keadaan yang terjadi, tanpa ada upaya apapun dari peneliti untuk memberikan tindakan.

Selanjutnya, pertanyaan kedua yang berkaitan dengan pandangan mahasiswa tentang seberapa berkaitankah Bahasa Inggris dengan disiplin keilmuan mereka, dijawab dengan pendekatan kualitatif. Untuk keperluan ini, kualitatif deskriptif digunakan sebagai metode pengumpulan dan analisis data. Sebagai alasan pemilihan, penelitian ini hanya bertujuan untuk

\footnotetext{
15 Patsy M. Lightbown and Nina Spada, How Languages are Learned. (Oxford: Oxford University Press, 2008).

16 John W. Creswell, Educational Research (Lincoln: Pearson, 2012), 22.

17 Ibid. 376. 
mendeskripsikan bagaimana mahasiswa memandang proses pembelajaran bahasa inggris di UIN Sunan Ampel Surabaya.

2. Subjek Penelitian

Sebagaimana disebutkan di atas, terdapat dua model pendekatan yang digunakan dalam penelitian ini, yakni kualitatif dan kuantitatif. Subjek yang diambil dalam dua penelitian ini adalah sama, akan tetapi dengan jumlah yang berbeda. Mahasiswa dengan latar jurusan keislaman di UIN Sunan Ampel Surabaya dipilih sebagai subjek penelitian.

Untuk menjawab pertanyaan pertama, 100 orang mahasiswa yang berasal dari 17 jurusan dengan latar keilmuan islam dalam 6 Fakultas di UIN Sunan Ampel Surabaya diambil sebagai sampel yang dipilih secara acak. Sedangkan pertanyaan kedua, yang menggunakan desain kualitatif, hanya mengambil 25 orang mahasiswa sebagai informan penelitian.

3. Instrumen Penelitian

Angket dan panduan wawancara adalah dua instrumen yang digunakan oleh peneliti untuk mengumpulkan data. Angket, dalam hal ini, digunakan untuk menjawab pertanyaan pertama. Dalam angket yang digunakan, terdapat 10 butir pertanyaan dalam Bahasa Indonesia yang akan membantu peneliti untuk mengetahui apa perspektif mahasiswa tentang pentingnya belajar Bahasa Inggris. Pertanyaan dalam angket ditulis berdasarkan hasil adaptasi dari berbagai sumber serta pengamatan peneliti.

Kemudian, panduan wawancara pun digunakan dengan tujuan membantu peneliti untuk menjawab pertanyaan kedua yang berkaitan dengan pandangan mahasiswa terhadap keberlangsungan proses pembelajaran Bahasa Inggris di UIN Sunan Ampel Surabaya. Dalam panduan wawancara, terdapat empat pokok pertanyaan yang diajukan kepada informan.

\section{Teknik Pengambilan Data}

Hal pertama yang dilakukan oleh peneliti ialah menyebarkan angket kepada para partisipan di 6 fakultas berlatar keilmuan Islam di UIN Sunan Ampel Surabaya. Kemudian, setelah mengumpulkan data untuk mengetahui jawaban pertanyaan pertama, peneliti menghubungi kembali sebanyak 25 partisipan untuk kembali menjadi subjek penelitian kedua. Partisipan terpilih berasal dari fakultas yang beragam di UIN Sunan Amel Surabaya. Dalam arti lain, pemilihan partisipan tidak hanya terpusat pada satu atau dua fakultas saja. 
5. Teknik Analisis Data

Dalam sebuah penelitian, teknik analisis data memiliki peranan nan signifikan dengan alasan bahwa teknik analisis data akan menentukan bagaimana peneliti memaknai data yang diperoleh. ${ }^{18}$ Berikut adalah langkahlangkah analisis data yang dilakukan peneliti:

a. Pertanyaan Penelitian 1

1) Data dikumpulkan

2) Peneliti mengelompokkan data ke dalam bentuk tabel

3) Peneliti menentukan rentang prosentase dari masing-masing opsi yang ada; Sangat setuju, setuju, kurang setuju, tidak setuju.

4) Peneliti menghitung prosentase tiap-tiap pernyataan menggunakan skala likert, kemudian digolongkan ke dalam rentang prosentase yang ada. Contoh, prosentase respon mahasiswa terhadap pernyataan pertama (seteelah dihitung dengan skala likert) adalah 97\%, yang maknanya adalah sangat setuju. Maka persepsi mereka adalah positif, dalam arti mereka setuju bahwa mempelajari Bahasa Inggris adalah hal yang penting.

5) Setelah menentukan prosentase masing-masing pertanyaan, peneliti menghitung secara garis besar jumlah prosentase negatif dan positif.

6) Peneliti mengambil kesimpulan; jika jumlah pernyataan dengan prosentase positif lebih banyak, maka respon mahasiswa adalah positif, begitu juga sebaliknya.

b. Pertanyaan Penelitian 2

1) Data dikumpulkan dari hasil wawancara

2) Masing-masing jawaban dari pertanyaan wawancara dikategorikan dengan menggunakan diagram lingkaran

3) Peneliti, melalui jawaban mahasiswa, mencoba mencari sebab-sebab atau alasan jawaban dan menuliskannya secara garis besar (pokokpokok persoalan)

4) Kesimpulan ditarik berdasarkan data-data yang ada

\section{F. Pembahasan}

1. Perspektif Mahasiswa dengan Background Jurusan Keislaman di UIN Sunan Ampel Surabaya tentang Pentingnya Belajar Bahasa Inggris

Pada penelitian ini, untuk menjawab pertanyaan pertama mengenai “Apa perspektif mahasiswa dengan background jurusan keislaman di UIN

\footnotetext{
${ }^{18}$ Nazir, Moh., Metode Penelitian (Jakarta: Ghalia Indonesia, 2013), 364.
} 
Sunan Ampel Surabaya tentang pentingnya belajar Bahasa Inggris?", terdapat sepuluh butir pernyataan yang terkait dengan peran penting belajar Bahasa Inggris oleh mahasiswa dengan background Jurusan keislaman di lingkungan UIN Sunan Ampel Surabaya dan itu ditujukan untuk mengukur perspektif mahasiswa tentang pentingnya belajar Bahasa Inggris. Seperti yang telah disajikan pada bab sebelumnya, subjek penelitian untuk menjawab pertanyaan penelitian pertama adalah 100 mahasiswa dengan background jurusan keislaman di lingkungan UIN Sunan Ampel Surabaya yang diambil secara acak mulai semester empat sampai semester akhir di program strata satu. Berikut adalah data yang didapatkan untuk menjawab pertanyaan pertama dalam penelitian:

Tabel I. Peta Jawaban Mahasiswa

\begin{tabular}{|c|c|c|c|c|c|c|}
\hline Pernyataan & $\begin{array}{c}\text { Sangat } \\
\text { Setuju }\end{array}$ & Setuju & $\begin{array}{c}\text { Kurang } \\
\text { Setuju }\end{array}$ & $\begin{array}{c}\text { Tidak } \\
\text { Setuju }\end{array}$ & Hasil & Respon \\
\hline 1 & 39 & 56 & 5 & - & $83,50 \%$ & + \\
\hline 2 & 15 & 24 & 37 & 24 & $57,50 \%$ & + \\
\hline 3 & 15 & 73 & 9 & 3 & $75 \%$ & + \\
\hline 4 & 11 & 43 & 42 & 4 & $65,25 \%$ & + \\
\hline 5 & 29 & 62 & 6 & 3 & $79,25 \%$ & + \\
\hline 6 & 5 & 19 & 61 & 15 & $53,50 \%$ & + \\
\hline 7 & 46 & 48 & 4 & 2 & $84,50 \%$ & + \\
\hline 8 & 40 & 52 & 7 & 1 & $81,25 \%$ & + \\
\hline 9 & 27 & 58 & 13 & 2 & $77,50 \%$ & + \\
\hline 10 & - & 8 & 52 & 40 & $83 \%$ & + \\
\hline
\end{tabular}

Pernyataan pertama tentang "Saya mempelajari Bahasa Inggris karena ia adalah bahasa global" mendapat respon positif dengan prosentase 83,50\% dari total mahasiswa. Dalam arti lain, pernyataan pertama mendapat respon positif dari mahasiswa yang menjadi partisipan penelitian. Sebagian besar dari mereka setuju bahwa Bahasa Inggris adalah Bahasa global, sehingga para mahasiswa mempelajarinya. Sedangkan untuk pernyataan kedua, respon mahasiswa adalah pernyataan negatif. Pernyataan "Saya adalah mahasiswa dengan latar jurusan keislaman, sehingga bahasa Inggris tidak terlalu saya butuhkan" memiliki respon negatif dengan nilai 57,50\%. Hal ini menandakan bahwa lebih dari separuh sampel mahasiswa dengan latar belakang jurusan keislaman, meski tidak berasal dari latar jurusan keislaman, tetap membutuhkan Bahasa Inggris dalam pembelajaran di jurusan masing-masing, 
itu dikarenakan pernyataan negatif direspon negatif, sehingga menghasilkan makna yang positif.

Pernyataan ketiga, yakni "Saya mempelajari Bahasa Inggris untuk mengakses sumber-sumber belajar berbahasa Inggris" mendapat prosentase respon sebesar $75 \%$ dari 100 mahasiswa partisipan. Hal ini menjadi indikasi bahwa sebagian besar sampel mahasiswa berlatar belakang jurusan keislaman mempelajari Bahasa Inggris karena literatur yang mereka gunakan yang berkenaan dengan jurusan mereka menggunakan Bahasa Inggris. Selanjutnya, pernyataan keempat yang berbunyi "Saya lebih suka dan nyaman belajar dalam bahasa Indonesia, daripada belajar dalam bahasa Inggris" mendapat respon negatif dengan prosentase sebesar 65,25\%. Ini membuktikan bahwa lebih dari separuh yang terlibat sebagai partisipan penelitian, selain belajar dalam bahasa Indonesia juga tidak menutup diri untuk belajar dalam Bahasa Inggris.

Pernyataan kelima yang berbunyi "Mempelajari bahasa Inggris dapat membantu saya mendapatkan banyak informasi baru yang dapat saya hubungkan dengan disiplin keilmuan saya" mendapat respon positif dari pertisipan atau responden penelitian. Hal ini dibuktikan oleh besarnya prosentase yang didapat oleh pernyataan ini, yakni 79,25\%. Hal ini berarti bahwa mahasiswa sepakat dengan diktum yang diajukan bahwa salah satu keuntungan yang didapat oleh mahasiswa dari mempelajari Bahasa Inggris ialah kemampuan mereka mengakses informasi-informasi baru yang berhubungan dengan disipin keilmuan masing-masing. Dengan kata lain, sedikit dari mahasiswa dengan latar belakang jurusan keislaman yang tidak mendapat manfaat dari belajar Bahasa Inggris di UIN Sunan Ampel. Selanjutnya, pernyataan keenam tentang "seluruh interaksi yang saya lakukan dengan dosen dan teman sekelas, tidak menggunakan Bahasa Inggris. Sehingga, belajar Bahasa Inggris tidak akan berguna banyak bagi saya" mendapat respon negatif dengan prosentase sebesar 53,50\%. Ini berarti bahwa meskipun Bahasa Inggris tidak dijadikan sebagai Bahasa Pengantar utama, mereka tidak memilih untuk menjadi apatis terhadap pentingnya mempelajari Bahasa Inggris.

Pernyataan ketujuh menyatakan "Penting bagi saya mempelajari Bahasa Inggris untuk membuka dan memperluas wawasan" mendapat prosentase sebesar $84,50 \%$ dari respon sampel mahasiswa yang berlatarbelakang jurusan keislaman. Ini berarti bahwa mahasiswa memberikan respon positif terhadap pernyataan nomor tujuh, yang berarti sebagian besar dari sampel mahasiswa menganggap bahwa mempelajari Bahasa Inggris dapat membantu mereka mengembangkan wawasan dengan 
mempelajari literatur keislaman yang berbahasa Inggris. Pernyataan selanjutnya adalah "Mempelajari bahasa Inggris dapat memperluas sudut pandang saya" mendapat respon sebesar 81,25\%. Ini mengindikasikan adanya anggapan sebagian besar sampel mahasiswa bahwa dengan mempelajari Bahasa Inggris, mereka dapat memiliki sudut pandang yang lebih luas dan terbuka dari sebelumnya.

Pernyataan selanjutnya, yakni pernyataan kesembilan "Dengan belajar Bahasa Inggris, saya akan banyak terbantu untuk meraih pencapaian akademik yang lebih tinggi dalam bidang yang saya tekuni" mendapat respon positif dari sampel mahasiswa yang berlatarbelakang jurusan keislaman dengan prosentase $77,50 \%$. Ini memiliki arti bahwa sebagian besar mahasiswa yang berlatarbelakang jurusan keislaman banyak terbantu untuk mencapai cakupan keilmuan yang lebih luas melalui belajar Bahasa Inggris. Terakhir, pernyataan kesepuluh yaitu "Tidak terlalu penting bagi saya untuk mempelajari bahasa Inggris, sebab ia adalah bahasa orang barat." mendapat respon 83\% yang berarti respon "tidak setuju" dari sampel mahasiswa yang berlatarbelakang jurusan keislaman karena sebagian besar dari mereka menganggap mempelajari Bahasa Inggris penting dengan alasan Bahasa Inggris bukan hanya bahasa orang-orang barat.

Dari data yang telah disajikan di atas, terdapat sepuluh butir pernyataan yang terkait dengan peran penting belajar Bahasa Inggris terhadap mahasiswa dengan background Jurusan keislaman di lingkungan UIN Sunan Ampel Surabaya dan itu ditujukan untuk mengukur perspektif mahasiswa tentang pentingnya belajar Bahasa Inggris. Dari 10 pernyataan tersebut, ditemukan bahwa seluruh butir pernyataan, baik dengan redaksi positif ataupun negatif, direspon secara positif oleh mahasiswa yang menjadi responden penelitian. Dalam arti lain, seluruh butir pernyataan memiliki makna yang direspon positif oleh sampel mahasiswa, sehingga bisa dikatakan bahwa perspektif mahasiswa terhadap pentingnya mempelajari Bahasa Inggris adalah positif.

2. Persepsi Mahasiswa tentang Keterkaitan Pembelajaran bahasa Inggris dengan Disiplin keilmuan Mahasiswa

Untuk menjawab pertanyaan penelitian kedua, yakni "Apakah pembelajaran Bahasa Inggris yang dilakukan di UIN Sunan Ampel Surabaya dapat membantu mahasiswa dengan background jurusan keislaman untuk memahami disiplin keilmuan terkait?", Peneliti mencoba mengajukan empat pertanyaan besar selama proses wawancara yang berlangsung. Sampel yang dipilih sebagai responden penelitian atau narasumber wawancara ialah 
sejumlah 25 orang yang berasal dari berbagai jurusan keislaman di UIN Sunan Ampel Surabaya.

Jawaban dari masing-masing pertanyaan pada akhirnya akan membantu mengarahkan peneliti untuk menarik jawaban akhir dari pertanyaan penelitian kedua. Pada pertanyaan pertama, peneliti bertanya tentang apa pandangan mahasiswa tentang keberlangsungan proses pembelajaran Bahasa Inggris di UIN Sunan Ampel Surabaya. Kemudian, pada pertanyaan kedua, diajukan pertanyaan tentang peningkatan kemampuan berbahasa yang dicapai oleh mahasiswa setelah mengikuti proses pembelajaran. Ketiga, beranjak pada pertanyaan inti yakni tentang apakah kemampuan Bahasa Inggris yang dimiliki mahasiswa dapat berkaitan langsung dengan disiplin keilmuan mahasiswa. Kemudian, pertanyaan keempat hadir sebagai tindak lanjut dari pertanyaan ketiga.

Diagram di bawah ini menunjukkan jawaban mahasiswa terhadap pertanyaan pertama, yakni "Apa pendapat anda tentang keberlangsungan proses pembelajaran bahasa Inggris di UIN Sunan Ampel Surabaya?”

Diagram I. Jawaban Pertanyaan Wawancara Pertama

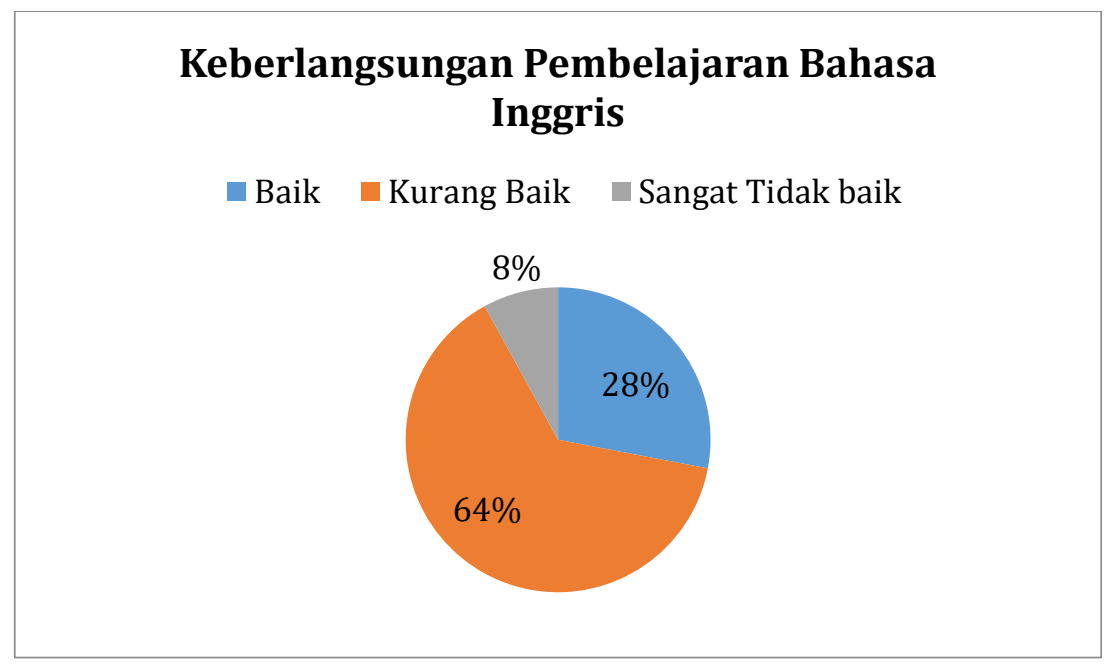

Dari diagram lingkaran di atas, dapat dilihat dengan jelas bahwa sebagian besar responden menganggap bahwa proses pembelajaran Bahasa Inggris yang berlangsung di UIN Sunan Ampel Surabaya belum berjalan maksimal. Hal ini dibuktikan oleh jumlah mahasiswa yang menganggap bahwa pembelajaran masih berlangsung dengan kurang baik, yakni sejumlah 16 orang atau $64 \%$ dari total responden. Selain itu, sejumlah 2 mahasiswa atau sekitar $8 \%$ dari total responden. Sedangkan, hanya terdapat 7 
mahasiswa atau sekitar 28\% dari total responden yang menganggap bahwa proses pembelajaran Bahasa Inggris telah berlangsung dengan cukup baik.

Terdapat beberapa alasan yang diajukan oleh mahasiswa yang menganggap bahwa proses pembelajaran Bahasa Inggris yang berlangsung di UIN Sunan Ampel Surabaya kurang baik. Peneliti mengelompokkan alasan mahasiswa menjadi empat garis besar, yakni: Tenaga pendidik kurang kompeten, konten dan aktivitas kurang disesuaikan dan tidak menarik, presensi menjadi standar utama, kegiatan pembelajaran dilakukan hanya sebagai formalitas, serta alokasi waktu yang tidak cukup.

Terkait dengan alasan pertama, yakni Tenaga pendidik kurang kompeten, mahasiswa menyebutkan beberapa bentuk ketidak kompetenan Dosen atau Tenaga Pengajar, diantaranya: Tenaga Pengajar tidak memahami materi dengan baik, sehingga sering terjadi kerancuan dalam penjelasan mereka. Bentuk lainnya ialah, pengajar tidak memahami bagaimana cara mengajarkan Bahasa Inggris yang baik serta tidak memberikan ruang yang cukup bagi mahasiswa untuk terlibat dalam penggunaan bahasa. Selain itu, Pengajar yang jarang masuk juga dianggap oleh mahasiswa sebagai salah satu penyebab ketidakefektifan pembelajaran. Terakhir, mahasiswa beranggapan bahwa Dosen atau Tenaga Pengajar hanya intens bertukar pengetahuan dengan mahasiswa yang memiliki kemampuan Bahasa Inggris yang cukup baik adalah sebuah masalah. Singkat kata, secara konten dan pedagogi pembelajaran yang dimiliki oleh Dosen atau Tenaga Pengajar bahasa Inggris dianggap belum cukup baik oleh mahasiswa.

Alasan kedua, yakni konten dan aktivitas kurang disesuaikan dengan kebutuhan dan tidak menarik. Mengemukakan ini, para mahasiswa yang menjadi informan menyertakan beberapa alasan diantaranya: Kegiatan berbatas pada aktivitas translasi, monoton dan membosankan, dosen tidak memaksimalkan fasilitas yang ada, seperti LCD, konten kurang sesuai dengan kebutuhan mahasiswa, serta tidak ada waktu yang cukup untuk aktivitas speaking.

Serupa dengan beberapa mahasiswa yang menjawab bahwa proses pembelajaran berlangsung kurang baik, dua mahasiswa yang secara ekstrim mengatakan bahwa pembelajaran berlangsung dengan tidak baik juga mengemukakan beberapa alasan atas jawaban mereka, yakni: Kompetensi pengajar jauh dari standar serta mereka menganggap bahwa proses pembelajaran adalah formalitas semata.

Di lain sisi, terdapat 7 mahasiswa yang menganggap bahwa proses pembelajaran bahasa Inggris di UIN Sunan Ampel telah berlangsung dengan cukup baik. Berikut adalah beberapa alasan atas jawaban yang mereka 
berikan: pengajar menarik, pembelajaran memberi dampak pada kemampuan berbahasa mahasiswa, banyak praktek, serta pembelajaran dilakukan cukup sesuai dengan ekspektasi mahasiswa.

Pertanyaan kedua dari wawancara ialah "Setelah Anda mengikuti pembelajaran bahasa Inggris, adakah Anda dapat menemui banyak perubahan pada kemampuan berbahasa Anda?". Merespon pertanyaan ini, 13 orang mahasiswa atau sekitar $52 \%$ dari total reponden menganggap bahwa mereka tak mengalami peningkatan apapun dalam kemampuan Bahasa Inggris mereka setelah mengikuti proses pembelajaran. Selanjutnya, 12 mahasiswa atau sekitar $48 \%$ dari total responden mengatakan bahwa mereka mendapati kemampuan Bahasa Inggris meningkat; Satu orang dengan peningkatan signifikan, sedang yang lain hanya sedikit meningkat. Berikut adalah gambaran jawaban mahasiswa terhadap pertanyaan kedua dalam wawancara:

Diagram II. Jawaban Pertanyaan Wawancara Kedua

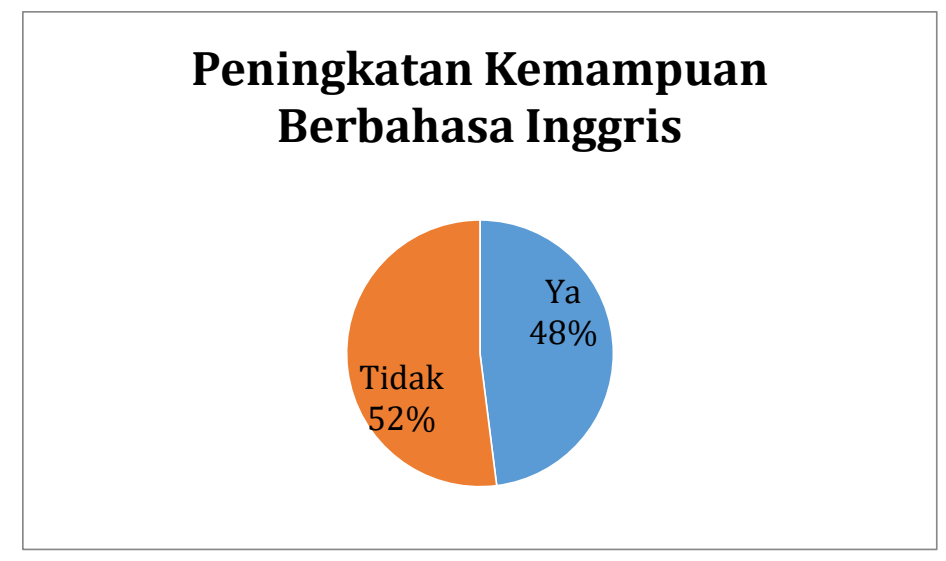

Kemudian, pertanyaan ketiga dari wawancara ialah "Kemampuan Bahasa Inggris yang Anda miliki, apakah dapat membantu Anda memahami atau mendalami disiplin keilmuan yang ditekuni?". Berikut adalah gambaran jawaban mahasiswa terhadap pertanyaan ketiga:

\section{Diagram III. Jawaban Pertanyaan Wawancara Ketiga}




\section{Keterkaitan Kemampuan Bahasa Inggris dengan Disiplin Keilmuan}

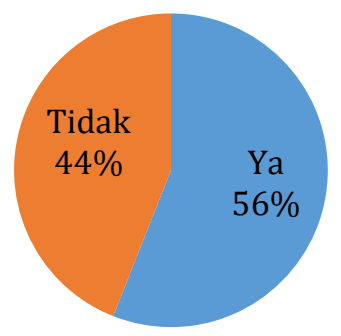

Dari diagram di atas, dapat dilihat bahwa 14 orang mahasiswa mengatakan bahwa kemampuan Bahasa Inggris yang dimiliki dapat membantu mereka dalam memahami disiplin keilmuan terkait. Bentuk dari keterpakaian kemampuan mereka ialah, mengerjakan tugas dengan pengantar bahasa asing, memahami Istilah dengan Bahasa Inggris, mengakses literatur berbahasa Inggris terkait disiplin keilmuan, serta memahami seminar berbahasa Inggris terkait dengan rumpun keilmuan. Sebelas orang lainnya atau sekitar $48 \%$ dari total responden mengatakan bahwa mereka belum dapat menemukan kegunaan Bahasa Inggris dalam upaya mereka memahami disiplin keilmuan terkait.

Sehubungan dengan hal di atas, mahasiswa yang belum menemukan keterkaitan antara kemampuan bahasa Inggris dengan disiplin keilmuan mereka memberikan beberapa saran untuk dilaksanakan dalam proses pembelajaran, diantaranya:

a. Pengajar harus mendorong mahasiswa untuk melakukan studi mandiri dengan memberikan materi yang memuat konten keilmuan terkait

b. Pengajar dapat memasifkan komunikasi personal dengan mahasiswa

c. Pengajar harus tahu bagaimana menghadapi mahasiswa dengan level kemampuan yang berbeda

d. Pembelajaran harus didesain menjadi lebih efektif dan atraktif

e. Pengajar harus membuat rencana pembelajaran yang baik lantas mengaplikasikannya

f. Kualitas dosen perlu ditingkatkan; pedagogi dan konten pembelajaran

g. Desain dan konten pembelajaran sesuai dengan spesifikasi keilmuan mahasiswa, atau dapat dikatakan bahwa pembelajaran harus berbasis ESP

h. Ruang bagi mahasiswa untuk melakukan praktek harus dibuka luas 


\section{G. Kesimpulan}

Berdasarkan hasil analisa data yang dilakukan dalam penelitian, terkait pertanyaan pertama dapat dilihat bahwa mahasiswa yang terlibat sebagai responden memberikan respon positif terhadap anggapan bahwa mempelajari Bahasa Inggris adalah hal yang penting. Hal ini mengindikasikan bahwa mahasiswa dengan latar jurusan keislaman di UIN Sunan Ampel Surabaya menganggap bahwa mempelajari Bahasa Inggris adalah hal yang diperlukan.

Terkait dengan pertanyaan kedua, yakni persepsi mahasiswa tentang apakah pembelajaran Bahasa inggris yang dilakukan di UIN Sunan Ampel Surabaya telah dapat membantu mereka memahami disiplin keilmuan masingmasing, hasil wawancara menunjukkan bahwa sebagian besar mahasiswa menganggap bahwa pembelajaran belum dapat memberi banyak sumbangsih bagi upaya mereka dalam mengintegrasikan kemampuan Bahasa Inggris dengan disiplin ilmu yang ditekuni. Hal ini disebabkan oleh kurang efektifnya proses pembelajaran yang dilakukan, sehingga mahasiswapun tak dapat berbuat banyak dengan kemampuan Bahasa Inggris yang dimiliki.

Selain dari dua hal di atas, hal lain yang dapat disimpulkan dari penelitian ini ialah ditemukannya fakta bahwa mahasiswa dengan latar jurusan keislaman UIN Sunan Ampel Surabaya telah menganggap bahwa mempelajari Bahasa Inggris adalah suatu hal yang dibutuhkan, akan tetapi tidak cukup terfasilitasi dengan baik oleh proses-pembelajaran yang telah berlangsung. Untuk mengatasi hal ini, terdapat beberapa masukan yang diberikan oleh mahasiswa, yakni peningkatan kualitas Dosen baik dalam muatan konten dan pedagogi, penyediaan ruang komunikasi yang cukup, serta penyesuaian materi pembelajaran dengan kebutuhan keilmuan mahasiswa (ESP).

\section{H. Daftar Pustaka}

Al-Khairi, Muhammad H., "English as A Foreign Language Learning Demotivational Factors As Perceived By Saudi Undergraduates", European Scientific Journal, 9 (November, 2013)

Bhatia, Vijay, et al, ESP in the 21th Century: ESP Theory and Application Today.

Proceeding of JACET 50th Commerative International Convention.

Creswell, John W, Educational Research (Lincoln: Pearson, 2012)

Crystal, David, English as Global Language (New York: Cambridge University Press, 1997).

Crystal, David. English as Global Language (New York: Cambridge University Press, 2003)

Dornyei, Zoltan, Teaching and Researching Motivation, (Harlow: Longman. 2001)

Graddol, David, The Future Of English?. (London: The British Council, 1997). 
Kaplan, Robert B, Language in The Global Context: Implication for The Language Classrooms. (Singapore: SEAMEO RECL. 2000).

Lightbown, Patsy M. and Nina Spada, How Languages are Learned. (Oxford: Oxford University press, 2008. Third edition).

Nazir, Moh, Metode Penelitian (Jakarta: Ghalia Indonesia, 2012).

Rohmah, Zuliati. "English as A Global Language: Its Historical Past and Its Future". Indonesian Scientific Journal Database. 1 (Vol. 33, 2005).

Rohmah, Zuliati. "English as global Language", Journal Bahasa dan Seni, (Universitas Negeri Malang, 2015).

Sheikh, Ismail Ahmad, et al., "Attitudes and Motivation toward Learning the English Language among Students from Islamic Education System Background: Exploring The Views of Teachers", Journal of Education and Learning, 3 (Vol. 8, 2014).

The Atlantic. 2015. The hidden Bias of Science's Universal Language, www.theatlantic.com. (Diakses pada 10 April 2015).

Why Learn English. 2015. www.antimoon.com. (Diakses pada 10 April 2015) 